\title{
WHY IS ETHNIC MINORITY POVERTY SEVERE? THE CASE OF RURAL VIETNAM
}

\author{
Linh Thuy \\ Nguyen $^{1+}$ \\ (D) Christopher Gan ${ }^{2}$ \\ Baiding $\mathbf{H u}^{3}$
}

\author{
'Lincoln University, Canterbury, New Zealand; Hue College of Economics, \\ Hue University, Vietnam. \\ 'Email:Linh.Nguyen@_lincolnuni.ac.nz Tel: +64.226-515-638 \\ ${ }^{2, s}$ Lincoln University, Canterbury, Nerw Zealand. \\ ${ }^{2}$ Email:Christopher.gan@lincoln.ac.nz Tel: +64-34-230-227 \\ ${ }^{s}$ Email: baiding:hu@lincoln.ac.nz Tel: +64-34-230-231
}

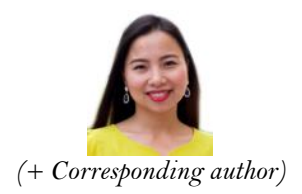

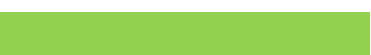

Article History

Received: 2 August 2021 Revised: 30 August 2021 Accepted: 14. September 2021 Published: 28 September 2021

\section{Keywords}

Rural ethnic minorities Poverty

Poverty intensity

Real per capita expenditure

Fractional logit model

Binary logit model.

JEL Classification:

I32; I3 1; I38.

\section{ABSTRACT}

In Vietnam, poverty is prevalent and extremely severe among rural ethnic minorities (REM). Despite a number of studies on characteristics of poverty, very few studies comprehensively examine the determinants of poverty intensity. This study employs binary and fractional logit models to investigate the determinants of poverty and the poverty intensity of the REM. Data are obtained by combining the 2012, 2014, and 2016 Vietnam Household Living Standards Surveys. The results show that education, wage-paying employment, housing conditions, and domestic remittances reduce poverty and its intensity. Poverty incidence reduction also hinges on development programmes on credit and scholarships. The likelihood and shortfall of poverty declined for households residing in the Red River and Mekong Deltas, and in southeast Vietnam. However, language barriers, farm size and overseas remittances influenced the poverty intensity but not the likelihood of poverty. Our results suggest that previous studies using only logit models have neglected several influences of poverty intensity, which the current research overcomes.

Contribution/ Originality: This is the first study that investigates both the determinants of REM's poverty and poverty intensity in the new era of economic development of Vietnam. It contributes to the existing poverty literature by providing improved empirical evidence to explain why the REMs have been economically and socially disadvantage.

\section{INTRODUCTION}

Over the past 30 years, Vietnam has achieved substantial progress in its socio-economic development and poverty alleviation (Glewwe, Agrawal, \& Dollar, 2004). The national poverty headcount ratio reduced significantly during the period of 1993 - 2016, from 58.1\% to 9.8\% (General Statistics Office of Vietnam (GSO, 2018)). Despite the nation's success in poverty alleviation, many ethnic minority households still live below the poverty line. This fact has prompted the government to launch poverty reduction programmes. Although they have received substantial national and international assistance, these anti-poverty programmes have not been particularly effective, in part, because they do not meet the ethnic minority's needs (Bui, Nguyen, \& Pham, 2017; Nguyen, Kompas, Breusch, \& Ward, 2017; Van de Walle \& Gunewardena, 2001). As a result, the poverty headcount ratio 
remains exceptionally high (44.6\% in 2016) among the ethnic minority group. In short, many ethnic minority households live in persistent poverty (GSO, 2018). Moreover, the ethnic minorities' poverty gap ${ }^{1}$ is more severe than that of the ethnic majority. In 2016, the ethnic minorities' poverty gap was $13.5 \%$ compared with only $0.5 \%$ for the ethnic majority. ${ }^{2}$

Scholars studying ethnic minority poverty in Vietnam have identified determinants related to location, and socio-economic and cultural characteristics. Specifically, ethnic minority poverty is distributed unevenly across Vietnam; it is associated with the uneven distribution of social and economic resources (Baulch \& Masset, 2003; Baulch, Nguyen, Phuong, \& Pham, 2010; Imai, Gaiha, \& Kang, 2011). Ethnic minority poverty is often more prominent in disadvantaged geographic locations like rural, remote and steep upland areas (Epprecht, Müller, \& Minot, 2011; Imai et al., 2011; WB, 2009). Scholars have tended to focus on the Midlands and Northern Mountains (MNM), Northern and Coastal Central (NCC), and Central Highlands (CH) of Vietnam because they are the poorest regions, with the highest levels of poverty (Nguyen et al., 2017; Pham, Bui, \& Dinh, 2003; Tran, 2016). Unique characteristics associated with ethnic minority communes, such as an inability to speak Vietnamese is considered barriers to their participation in national economic expansion and poverty reduction programmes (Baulch et al., 2010; Nguyen et al., 2017; Vasavakul, 2003).

This paper explores the determinants of poverty in relation to ethnic minorities in Vietnam. In particular, the study uses a binary logit regression model to test the factors that determine the likelihood of ethnic minority poverty. As poverty is concentrated and more pronounced in rural areas where there are more ethnic minority communes (Hinsdale et al., 2013; WB, 2018)3 , the paper focuses on this group: Rural ethnic minorities or REM for short. Although a large number of studies have identified characteristics of poverty, there are very few comprehensive studies on poverty in rural ethnic minority households in Vietnam. This study explores the social problems that accompany poverty at individual, household and regional levels. We also examine the influences of programmes designed to help the REM: the study uses various empirical models to assess the credit, scholarship, pension and free healthcare programmes.

A binary logit regression model can estimate only the likelihood that a household is poor. It cannot estimate the effects of various factors on the poverty gap (an indicator that shows how poor the poor are). The poverty headcount ratio is the most commonly used measure to determine the proportion of poor people residing in an area. Whereas two areas may have the same poverty headcount ratio, the total cost of lifting all the poor up to the poverty threshold may vary in different regions. The poverty headcount ratio does not include information about the poverty gap, or how far below the poverty line an individual's spending falls (Foster et al., 1984). This gap is the intensity of the poverty (known as the poverty intensity); governments need this information to determine how much funding to allocate for poverty elimination. Rodgers and Rodgers (2000) claim that most empirical studies of poverty in Australia and other countries lack evidence of poverty intensity. Moreover, very few studies have attempted to model poverty intensity. For example, Osberg and Xu (1999) did not model the influences of poverty intensity in Canada. They note only that poverty intensity is increasing because of decreased social assistance. Others, who modelled poverty intensity, omit a number of predictor covariates in their studies. For example, Bhaumik, Gang, and Yun (2006) provide empirical evidence of the determinants of poverty intensity in Kosovo, but do not examine some key determinants such as access to safe water and credit. Likewise, Tran, Nguyen, Vu, and Nguyen (2015) provide some initial evidence of the determinants of poverty intensity in Northwest Vietnam, but ignore language barriers, remittances, and government support. To overcome this limitation, we determines the

\footnotetext{
${ }^{1}$ Poverty intensity is measured using the poverty gap ratio. This ratio shows how far the poor's consumption is under the poverty line (Foster, Greer, \& Thorbecke, 1984). See section 3.1 for further details.

${ }^{2}$ Data calculated by the author.

3 The WB (2018) figures show that in $2016,95 \%$ of poor ethnic minority households resided in rural areas.
} 
poverty intensity of the REM in Vietnam using a fractional logit model that is the most appropriate approach for estimating a fractional outcome variable (Papke \& Wooldridge, 1996).

Our study differs from prior research in two respects. First, we examines the determinants of poverty and poverty intensity in a middle-income country for the year 2009. In 2010, Vietnam implemented an updated the GSO-WB poverty monitoring system, based on the Vietnam Household Living Standards Survey (VHLSS), and a new method for measuring poverty (Dang, 2011; Gibson, Le, \& Kim, 2017). In 2010, the GSO designed a new sample frame for the VHLSS. This frame was based on a list of interviewed communes from the 2009 Housing and Population Census (HPC) (Hinsdale et al., 2013). As a result of the 2010 VHLSS findings, a new poverty line was calculated. The government also updated and improved the spatial cost-of-living indexes (Scolis). Before 2010, the VHLSSs used regional consumer price indexes (CPI) that provide inaccurate results when measuring spatial differences in living costs ${ }^{4}$ (Gibson et al., 2017; Hinsdale et al., 2013). This study is based on poverty measures that are calculated from real per capita household expenditure converted by the Scolis. Economic well-being and poverty measures enable a consistent comparison of these indicators over different times and regions. Secondly, the study merged three national surveys to generate a bigger study sample. This provides us with more information and thus increases the model's predictive precision.

The paper is organised as follows. Section 2 describes the data used for analysis. Section 3 outlines the study's empirical methods. Section 4 provides a descriptive analysis of the REM's expenditure, income and poverty measures. Section 5 discusses the results. Section 6 concludes the paper by outlining the policy implications of the study's findings.

\section{DATA}

We uses data from the 2012, 2014, and 2016 VHLSSs conducted by GSO. From 2010 onwards, the surveys used different sample frames and consumption calculations to reflect changes in living standards and poverty rates. The VHLSS was designed to systematically collect data related to the living standards of Vietnam's population, using geographically stratified sampling (Bui \& Imai, 2019). The sample selection process for the VHLSSs involves three-stages. The first stage involves selecting which communes to sample. In the second stage, organisers choose three enumeration areas (EAs) from within each selected commune. However, only one EA is used for each national survey. In the third stage, three households within the selected EA are interviewed to obtain both income and expenditure data. Both communes and EAs are selected with probability proportionate to size, the size being the number of households according to the 2009 HPC.

We use VHLSS data at the household level that include demographic and socio-economic characteristics and information about household participation in targeted programmes. By combining data from the three national surveys, our study obtained a sample size of 4,284 ethnic minority households living in 2,330 rural communes.

Our study analyses the REM's poverty rates and the intensity of poverty using real per capita household expenditure (RPCE). We uses expenditure because it reflects a household's actual material living standards (Mukherjee \& Benson, 2003). Our study is based on the assumption that members of a single family use common family resources. These resources are shared equally among the family members, thus, each person's standard of living is similar. This assumption allows the study to use the nominal expenditure per capita data published in the VHLSSs.

However, the national surveys and the expenditure module were conducted over different time periods and in different regions. To ensure consistent comparisons over time and geography, we converted nominal household expenditure into the constant prices of January 2010 using three types of price indexes. These data were converted

\footnotetext{
${ }^{4}$ The regional CPIs collected in the VHLSSs before 2010 were inaccurate because of problems in the data collection of these indexes: 1) the good and services were not spatially representative; 2) changes in the price index were included with changes in the quality of goods.
} 
using three steps: (1) using the within-year monthly consumer price index (CPI) included in each database, the nominal household expenditures were converted into the constant prices of January in each survey year (Benjamin, Brandt, \& McCaig, 2017; GSO, 2015, 2016; Nguyen et al., 2017). The conversion excluded the price change by survey month as the number of interviewed households in each survey were allocated in different months of the year. This conversion was necessary to correct for high inflation in different years; (2) to exclude changes in prices among the three surveyed years, we used the annual CPI (with the base year, 2010, published by the WB) to adjust January prices from 2012, 2014, and 2016 into January 2010 prices; and (3) we used the Scolis index to convert expenditure and remove geographical differences associated with living costs (Gibson et al., 2017). Using these steps enabled us to generate total real household expenditure. Other monetary variables were also converted into January 2010 prices using the same conversion method. We applied cross-sectional sampling weights (the original weights provided in each survey) to ensure the precision of the descriptive statistics and model estimations.

\section{METHODOLOGY}

First, the sampled REM households were divided into two groups using the expenditure poverty line developed by the GSO and the $\mathrm{WB}^{5}$ : the rural poor ethnic minorities (RPE) and the rural non-poor ethnic minorities (RNPE). The study used three common poverty measures, developed by Foster et al. (1984), to calculate the REM's poverty headcount, intensity and severity. Next, we used a binary logit model to estimate the probability of being poor, combined with a fractional logit model to estimate the determinants of poverty intensity.

\subsection{Poverty Measures}

This section discusses three poverty indexes developed by Foster et al. (1984). These are, the incidence of poverty, the poverty gap and the severity of poverty. These indexes are given as:

$$
\mathrm{P}_{\alpha}=\frac{1}{\mathrm{~N}} \sum_{\mathrm{i}=1}^{\mathrm{q}}\left(\frac{\mathrm{Z}-\mathrm{Y}_{\mathrm{i}}}{\mathrm{Z}}\right)^{\mathrm{a}}
$$

In Equation 1, $\mathrm{N}$ is the population; $\mathrm{Y}_{\mathrm{i}}$ represents the $i$-th household's per capita expenditure; $\mathrm{Z}$ is the poverty line (threshold); and $\mathrm{q}$ is the number of people with average per capita expenditure below the poverty line;

If $\alpha=0$, then $P_{\alpha}=P_{0}=\frac{q}{\mathbb{N}}$, is the headcount index (incidence of poverty) which measures the percentage of the population living in poverty. $\mathrm{P}_{0}$ is the most commonly-used measure of poverty because it is easily understood and simple to calculate. However, $\mathrm{P}_{0}$ counts only the number of poor people; it does not take into account the intensity and depth of poverty in a country or region. In other words, $\mathrm{P}_{\mathrm{o}}$ just classifies all individuals below the poverty line as poor; it cannot distinguish who is poorer or the poorest in that country or region.

To measure the intensity of poverty, Foster et al. (1984) developed the poverty gap index. If $\alpha=1$, then $\mathrm{P}_{\alpha}=\mathrm{P}_{1}=\frac{1}{\mathrm{~N}} \sum_{\mathrm{i}=1}^{\mathrm{q}}\left(\frac{\mathrm{Z}-\mathrm{Y}_{\mathrm{i}}}{\mathrm{z}}\right)^{1}$, represents the "poverty gap or the depth of poverty". This index is used to measure the distance between the poor's expenditure and the poverty threshold. $\mathrm{P}_{1}$ takes a value between $\mathrm{O}$ and 1 . A larger poverty gap means more severe poverty. The non-poor have a zero poverty gap. $\mathrm{P}_{1}$ is more effective for measuring poverty than $P_{0}$ because $P_{1}$ reflects the extent of poverty and the distribution of the poor under the poverty benchmark. $\mathrm{P}_{1}$ can be used by states to determine how much they must spend to lift the poor out of poverty or

\footnotetext{
${ }_{5}^{5}$ The nominal poverty threshold was VND 10,456 or 11,563 thousand per year a person in 2012 and 2014, respectively. In 2016, the poverty line was VND 11,630 thousand per person annually.
} 
above the poverty line. However, this measure of poverty does not consider differences in the severity of poverty because it assigns equal weight to each individual's poverty gap.

If $\alpha=2$, then $P_{a}=P_{2}=\frac{1}{N} \sum_{i=1}^{q}\left(\frac{Z-Y_{i}}{Z}\right)^{2}$, represents the mean value of "squared poverty gap" of each poor person. $\mathrm{P}_{2}$ is called "poverty severity." This indicator refers to the inequality that exists among the poor: a higher weight is assigned to those whose level of expenditure is the furthest away from the poverty line (Coudouel, Jesko, \& Quentin, 2002).

\subsection{Binary Logit Model}

Binary logit regression is employed to estimate the probability that a REM household is poor. The logit model takes the form (Tran et al., 2015) outlined below:

$$
\mathrm{p}_{\mathrm{i}}=\mathrm{P}(\mathrm{Y}=1 \mid \mathrm{X})=\frac{\operatorname{Exp}\left(\beta_{S}^{f} \mathrm{X}_{S}^{t}\right)}{1+\operatorname{Exp}\left(\beta_{S}^{f} \mathrm{X}_{5}^{f}\right)}
$$

In Equation 2, $p_{\mathrm{i}}(\mathrm{Y}=1 \mid \mathrm{X})$ denotes the likelihood that the $i$-th household is poor; $\mathrm{Y}$ is a binary outcome that has

two values: 1 (a poor household) and o (a non-poor household); the coefficients $\beta_{5}^{s}$ represents the parameters that are estimated in the model; and $\mathrm{X}_{S}^{s}$ represents the model covariates. Appendix A, Table A1 provides definitions, measurements and expected signs for the explanatory variables.

A linear function of the covariates in Equation 2 is presented as follows:

$$
\beta_{S}^{s} X_{5}^{s}=\alpha+\sum_{\mathrm{h}=1}^{H} \beta_{h} H H H_{i \mathfrak{h}}+\sum_{j=1}^{J} \gamma_{j} H H C_{i j}+\sum_{i=1}^{L} \lambda_{1} R E G_{i l}
$$

In Equation 3, $H H H_{i \mathrm{in}}, H H C_{i j}$, and $R E G_{i \mathfrak{i n}}$ are the household head, household, and regional characteristic vectors, respectively. We used common variables to analyse the determinants of poverty: age, gender, education, employment, marital status, living conditions, and assets. Regional dummies were used to control for the spatial impact of unobserved regional characteristics on the poverty of ethnic minorities. In addition, our study added ethnic minority languages (a unique REM characteristic), to the models to assess how language barriers contribute to poverty. To evaluate the efficiency of public resources allocation for the development of the REM, the study used free health insurance, scholarships, pensions and credit. Apart from employment, income from family members living overseas can help to reduce poverty (Acharya \& Leon-Gonzalez, 2012); thus, we added both domestic and overseas remittance variables into Equation 3. Finally, the interview year was used to control for unobserved characteristics in each year. 
The notations H, J, and L refer to the total number of covariates representing the household head, household,

and regional characteristics, respectively; $\beta, \gamma$, and $\lambda$ represent the vector of coefficients for the household head, household, and regional characteristics, respectively.

The primary objective was to examine the influences of the likelihood and intensity of poverty of the REM. The selected independent variables in the logit model were based on the WB (2009) guidelines and previous empirical studies which show likely exogenous determinants of poverty. To control for effects of development programmes, the logit model in Equation 2 was estimated first with, and then without, the four variables related to development programme variables. After excluding the four variables, the logit model was estimated without the domestic and overseas remittance variables. The purpose of this process was to test whether there was a correlation between remittances and other explanatory variables in the models.

\subsection{Fractional Logit Model}

The study identifies the factors that influence the REM's poverty gap using the fractional logit model suggested by Papke and Wooldridge (1996). As the poverty gap is a fractional outcome variable, we employed a nonlinear function to estimate the expected values of the poverty gap conditional on a vector of covariates:

$$
\mathrm{E}\left(\mathrm{Y}_{\mathrm{i}} \mid X_{\mathrm{i}}\right)=G\left(\beta_{S}^{v} \mathrm{X}_{S}^{s}\right)
$$

In Equation 4, $\mathrm{Y}_{\mathbb{i}}$ is the poverty gap of the $i$-th household in the REM sample; $0 \leq \mathrm{Y} \leq 1$; the coefficients $\beta_{S}^{p}$ are

estimated parameters in the model and $X_{S}^{p}$ represents the predictor variables; $G\left(\beta_{S}^{v} X_{S}^{v}\right)$ indicates the logit cumulative distribution function of poverty intensity, expressed by $P_{i}=P\left(\mathrm{Y}_{i}=1 \mid X_{i} ; \beta\right)$, and $\mathrm{Y}_{i} \in[0,1]$. Therefore, the model can be specified as follows:

$$
\mathrm{E}\left(\mathrm{Y}_{\mathrm{i}} \mid X_{\mathrm{i}}\right)=\frac{\operatorname{Exp}\left(\beta_{S}^{t} \mathrm{X}_{S}^{r}\right)}{1+\operatorname{Exp}\left(\beta_{S}^{r} \mathrm{X}_{5}^{r}\right)}
$$

With regards to the fractional outcome variable (poverty intensity) in Equation 5, we chose not to use OLS and binomial logit regression because neither are suitable (Papke \& Wooldridge, 2008). OLS estimation does not guarantee an accurate prediction with values lying between 0 and 1 . The log-odds ratio approach requires that values are either 0 or 1 . The fractional logit model can deal with the shortcomings of OLS and log odds approaches and model a proportional outcome. This model can be distinguished from the binary logit model that defines $\mathrm{Y}$ with

only two values: $O$ and 1 . The maximum likelihood method cannot yield robust estimates for $\mathrm{E}\left(\mathrm{Y}_{\mathrm{f}} \mid X_{\mathrm{f}}\right)$ since it cannot overcome the distributional failure (Papke \& Wooldridge, 1996). Therefore, we use the quasi-likelihood method to estimate the parameters in the fractional logit model.

According to Bhaumik et al. (2006), the factors that determine the poverty intensity are similar to those that affect the probability of poverty. Therefore, we estimated a fractional logit model using the same covariates with the binary logit model in Equation 2. 


\section{LIVING STANDARDS AND POVERTY IN RURAL ETHNIC MINORITY “COMMUNES”}

The result shows that rural poverty is worse for the ethnic minorities than for the majority. These results are based on three measures of poverty. Table 1 shows that the 2012 poverty headcount ratio for the REM was $60.97 \%$, substantially higher than their majority counterparts (who had a poverty headcount ratio of $12.85 \%$ ). The poverty incidence decreased for both groups from 2012-2016 whereas the speed of poverty alleviation for the REM was slower than for the majority. From 2012-2016, the average poverty reduction rate was approximately $4.5 \%$ for the REM compared with $13 \%$ for the majority. The same patterns were identified for the depth and severity of poverty. The REM exhibited a consistently higher poverty gap ratio than the poor majority. In 2016, the REM's poverty gap was $14.28 \%$ compared with $0.72 \%$ for the poor majority.

Table 1 shows that the REM's living standards improved over the study period. However, the poor's living standards remained substantially lower than the non-poor. The RPE's average real expenditure per capita was only $40 \%$ of the RNPE. In 2016, the RPCE of the poor was VND 5,481.5 thousand compared with VND 13,813.1 thousand for the non-poor. Consistent expenditure gaps between the RPE and the RNPE (2.5 times) indicate limited improvement in the poor's living conditions.

Table-1. Rural ethnic minorities' income, expenditure and poverty measures in Vietnam (2012-2016).

\begin{tabular}{|c|c|c|c|c|}
\hline Year & 2012 & 2014 & 2016 & Average Growth (\%) \\
\hline \multicolumn{5}{|c|}{ Rural Ethnic Majority's Poverty Measures } \\
\hline Headcount Ratio & 12.85 & 8.54 & 4.49 & -13.0 \\
\hline Poverty Gap Ratio & 2.52 & 1.65 & 0.72 & -14.3 \\
\hline Poverty Severity & 0.77 & 0.5 & 0.19 & -15.1 \\
\hline \multicolumn{5}{|c|}{ Rural Ethnic Minorities' Poverty Measures } \\
\hline Headcount Ratio & 60.97 & 60.47 & 47.12 & -4.5 \\
\hline Poverty Gap Ratio & 20.07 & 20.15 & 14.28 & -5.8 \\
\hline Poverty Severity & 8.67 & 8.84 & 6.02 & -6.1 \\
\hline Per Capita Expenditure & 8522.8 & 8440.8 & 9887.1 & 3.8 \\
\hline Rural Poor Ethnic Minorities & 5418.1 & 5367 & 5481.5 & 0.3 \\
\hline Rural Non-poor Ethnic Minorities & 13372.2 & 13142.5 & 13813.1 & 0.8 \\
\hline Per Capita Income & 8439.3 & 9094.8 & 10069 & 4.5 \\
\hline Rural Poor Ethnic Minorities & 5561.1 & 5708 & 5880.8 & 1.4 \\
\hline Rural Non-poor Ethnic Minorities & 12935 & 14275.2 & 13801.3 & 1.6 \\
\hline \multicolumn{5}{|c|}{ Gap between the Rural Poor and the Non-poor Ethnic Minorities } \\
\hline Expenditure Gap & 2.5 & 2.4 & 2.5 & - \\
\hline Income Gap & 2.3 & 2.5 & 2.3 & - \\
\hline
\end{tabular}

Figure 1 shows that among the six regions, the RPE in the $\mathrm{CH}$ region were the poorest households, with an average RPCE of VND 4,890 thousand during the study period. The RPE in the Mekong River Delta (MRD) had the highest RPCE (VND 6,255 thousand). The Southeast was the most developed region in Vietnam; the RPE's RPCE was ranked third in the six regions.

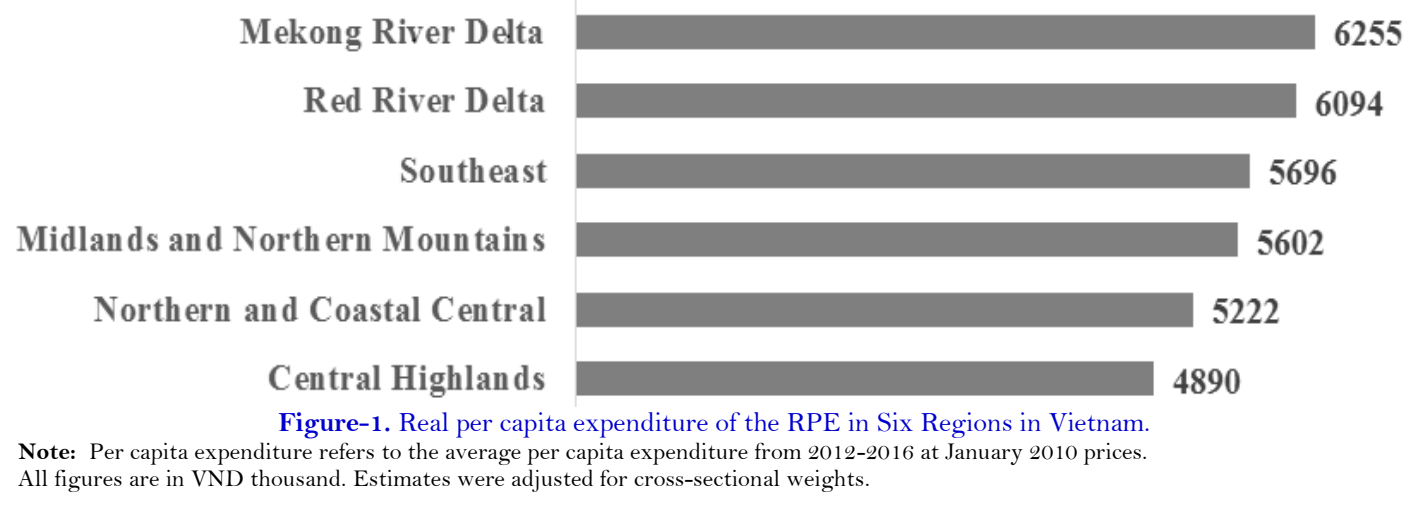


Differences in the RPCE between the two household groups (RPE and RNPE) are associated with variations in per capita income and income sources (Gallup, 2004). Table 1 shows that the income gap between the two groups was approximately 2.3 to 2.5 times between 2012 and 2016. Household income was generated from six main sources (see Figure 2). The analysis reveals that the RPE depend more on agricultural income than the RNPE. Wages and non-agricultural income occupied smaller shares in the RPE's total household income than for the RNPE. Likewise, income from remittances contributed a smaller share to the RPE's total household per capita income $(3.8 \%$ in 2016) than that of the non-poor (6.6\% in 2016). Although the RPE's share of aid for education and healthcare was higher (4.2\% in 2016) than the RNPE (1.7\%), the value of aid for the RPE (VND 246 thousand in 2016) was not much higher than the RNPE (VND 236.6 thousand). ${ }^{6}$

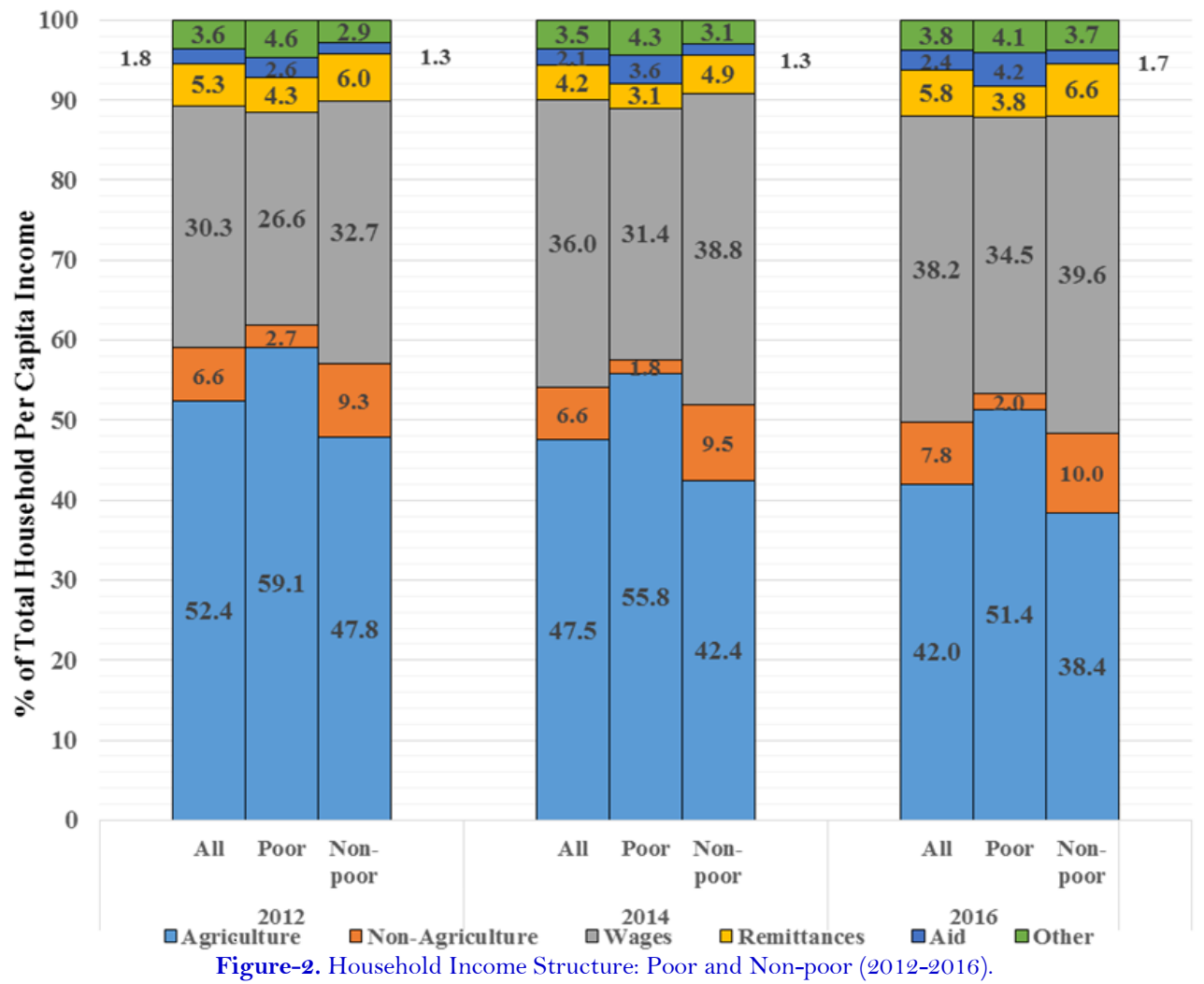

\section{RESULTS AND DISCUSSION}

For brevity, descriptive statistics for the explanatory variables in the empirical models are presented in Appendix A, Table A3. The results for the model estimates in Equation 2 and 5, without public assistance and remittances, ${ }^{7}$ are similar to the full models. These results indicate that public assistance and remittances are weakly correlated with other covariates in the empirical models. For this reason, we interpret the full model results in Table 2 .

\footnotetext{
${ }^{6}$ See Table A2 for more details.

7 The results for the model estimates without public assistance and remittances are unreported but available on request.
} 
Table-2. Binary and fractional logit regression model estimations.

\begin{tabular}{|c|c|c|c|c|c|}
\hline \multirow{2}{*}{ Variables } & \multicolumn{3}{|c|}{ Binary Logit Model } & \multicolumn{2}{|c|}{ Fractional Logit Model } \\
\hline & Coef. & OR & AME & Coef. & AME \\
\hline \multicolumn{6}{|c|}{ Household Head Characteristics } \\
\hline Age & $-0.014^{* * * *}$ & 0.986 & -0.002 & $-0.008^{*} * *$ & -0.001 \\
\hline Gender & -0.178 & 0.837 & -0.024 & -0.134 & -0.016 \\
\hline Schooling Years & $-0.069^{*} * *$ & 0.933 & -0.009 & $-0.034^{* * * *}$ & -0.004 \\
\hline Never Married & -0.533 & 0.587 & -0.072 & -0.143 & -0.018 \\
\hline Widowed & -0.162 & 0.851 & -0.022 & 0.076 & 0.009 \\
\hline Divorced/Separated & -0.443 & 0.642 & -0.060 & 0.071 & 0.009 \\
\hline Non-Farm Self-Employment & -0.231 & 0.794 & -0.031 & $-0.471^{* * * *}$ & -0.058 \\
\hline Wage-Paying Employment & $-0.564^{* * * *}$ & 0.569 & -0.076 & $-0.540^{* * * *}$ & -0.066 \\
\hline \multicolumn{6}{|l|}{ Household Characteristics } \\
\hline Language Barrier & 0.171 & 1.187 & 0.023 & $0.127^{* * * *}$ & 0.016 \\
\hline Household Size & $0.127^{*} * *$ & 1.135 & 0.017 & $0.128 * * *$ & 0.016 \\
\hline Working Rate & $-0.013^{*} * *$ & 0.987 & -0.002 & $-0.011^{* * *}$ & -0.001 \\
\hline Living Area & $-1.082^{* * * *}$ & 0.339 & -0.146 & $-0.521^{* * * *}$ & -0.064 \\
\hline Durable Goods & $-0.931^{* * * *}$ & 0.394 & -0.125 & $-0.277^{*} * *$ & -0.034 \\
\hline Tap Water & -0.296 & 0.744 & -0.040 & -0.249 & -0.030 \\
\hline Other Water & $0.727 * *$ & 1.539 & 0.058 & $0.262 * * *$ & 0.032 \\
\hline Toilet_Not Flush & $0.807 * * *$ & 2.242 & 0.109 & $0.597 * * *$ & 0.073 \\
\hline Toilet_No & $0.941 * * *$ & 2.562 & 0.127 & $0.830^{* * * *}$ & 0.101 \\
\hline Domestic Remittances & $-0.038^{*}$ & 0.963 & -0.005 & $-0.020^{*}$ & -0.002 \\
\hline Overseas Remittances & -0.098 & 0.906 & -0.013 & $-0.128^{* * * *}$ & -0.016 \\
\hline No Farmland & -0.401 & 0.670 & -0.054 & -0.194 & -0.024 \\
\hline $0.5 \mathrm{Ha}<=$ Farm Size $<1 \mathrm{Ha}$ & 0.115 & 1.122 & 0.016 & 0.007 & 0.001 \\
\hline $1 \mathrm{Ha}<=$ Farm Size $<1.5 \mathrm{Ha}$ & -0.225 & 0.799 & -0.030 & $-0.134^{*}$ & -0.016 \\
\hline Farm Size $>=1.5 \mathrm{Ha}$ & -0.151 & 0.860 & -0.020 & $-0.184^{* * * *}$ & -0.023 \\
\hline Health Insurance Premiums & $-0.007^{* * * *}$ & 0.993 & -0.001 & $-0.008^{* * * *}$ & -0.001 \\
\hline \multicolumn{6}{|l|}{ Development Programmes } \\
\hline Free Health Insurance Rate & 0.000 & 1.000 & 0.000 & -0.003 & 0.000 \\
\hline Scholarship & $-0.140^{* *}$ & 0.869 & -0.019 & -0.028 & -0.003 \\
\hline Pension & -0.068 & 0.934 & -0.009 & $-0.063^{*}$ & -0.008 \\
\hline Borrowing & $-0.295^{* * * *}$ & 0.745 & -0.040 & $-0.140^{* * * *}$ & -0.017 \\
\hline \multicolumn{6}{|l|}{ Regional Characteristics } \\
\hline Red River Delta & $-1.176^{* * * *}$ & 0.309 & -0.158 & $-0.578^{* * * *}$ & -0.071 \\
\hline Northern and Coastal Central & 0.122 & 1.130 & 0.017 & 0.092 & 0.011 \\
\hline Central Highlands & -0.204 & 0.816 & -0.028 & $0.1431^{* * *}$ & 0.018 \\
\hline Southeast & $-1.609^{* * * *}$ & 0.200 & -0.217 & $-0.705^{* *}$ & -0.086 \\
\hline Mekong River Delta & $-1.37 \mathrm{O}^{* * * *}$ & 0.254 & -0.185 & $-0.835^{* * * *}$ & -0.102 \\
\hline Year 2014 & $0.284^{* * *}$ & 1.329 & 0.038 & $0.156^{* * * *}$ & 0.019 \\
\hline Year 2016 & $-0.452^{* * * *}$ & 0.637 & -0.061 & $-0.306^{* * * *}$ & -0.037 \\
\hline Constant & $9.619^{* * *}$ & 15052.5 & & $1.596^{* * * *}$ & \\
\hline Observations & 4080 & & & 4080 & \\
\hline Pseudo R-Squared & 0.394 & & & 0.179 & \\
\hline Wald Chi-Square & $653.56^{* * * *}$ & & & $2359.4^{* * * *}$ & \\
\hline
\end{tabular}

Note: Model estimations were adjusted for cross-sectional weights. Coef: Estimated coefficient. OR: Odds ratio.

AME: Average marginal effects. Reference groups: Agricultural employment; Married; Water Source:_Cleaned,

Toilet_flush; 0 ha $<$ Farm Size $<0.5$ ha; Midlands and Northern Mountains.

**** $\mathrm{p}<0.01,{ }^{* * *} \mathrm{p}<0.05,{ }^{*} \mathrm{p}<0.1$

\subsection{Impact of Household-Level Factors on Poverty}

Table 2 shows the binary logit model results for the REM's poverty at the household level. The Wald chisquare (653.6) with a statistical significance of 0.01, shows that at least one of the explanatory variables affected the likelihood of falling into poverty. The pseudo R-squared (0.39) indicates that the binary logit model explains 
variations in the outcome variable (poor or non-poor households) (McFadden, 1977). ${ }^{8}$ Specifically, the logit model was $81 \%$ successful in predicting the likelihood that a household is poor. ${ }^{9}$ This result shows that the signs and significance levels of parameters in the logit model are identified as expected, except for employment, water sources, farm size, the free health insurance rate, and pension.

a) Household Head Characteristics. Table 2 shows that marital status had no impact on the likelihood of poverty for the REM during the study period. Similarly, our study found no evidence that female-headed households are more likely to live under the poverty line in REM communes in Vietnam. The household head's education level and age had positive effects on poverty reduction. Higher education levels and age significantly reduced the likelihood of poverty. Only wage-paying employment significantly affected the odds that the REM would be poor. Although it had a positive sign, the non-farm self-employment coefficient was statistically insignificant.

b) Household Characteristics. For demographic characteristics, the results show that household size and the number of working members were strong determinants of poverty in rural ethnic minority communes. In particular, an additional family member increased the risk of falling into poverty by $1.7 \%$, holding other variables constant. In contrast, the proportion of working members in a household had a positive effect on poverty reduction; a $1 \%$ increase in the percentage of working members led to a $0.2 \%$ decrease in the probability of poverty. Although it had a positive sign, the language barrier had an insignificant effect on the likelihood of poverty.

REM household's poverty was related to the residential area and durable assets; they reduced the likelihood of poverty for REM. Hygiene conditions were associated with poverty. The likelihood of living in poverty for the REM using simple toilets was $124 \%$ higher than that for the REM using flush toilets. ${ }^{10}$ Similarly, other water variable is significant among the three water source variables. Households that used untreated or purchased water (in bottles, jars, or small vehicles) were more likely to be poor than those who had access to clean, protected water from streams or dug wells.

Our study shows that although the farm size variables had the expected signs, none significantly affected poverty. These results indicate that the RPE may use farmland ineffectively or are unable to fully utilise the land to escape poverty; though more land area is associated with greater output and income, it also requires higher levels of expenditure. Low quality of the farmland may constrain the RPE's agricultural production. ${ }^{11}$ We found a positive link between health insurance premiums and poverty reduction. Similarly, domestic remittances significantly decreased the odds of the REM being poor; this was not true for overseas remittances.

We found that the impact of free health insurance and pension were not statistically significant in reducing the likelihood of poverty. These findings are consistent with Abrams, Nguyen, Murphy, Tran, and Wiljer (2016) who have provided evidence that in northern Vietnam the ethnic minorities with mental health issues who live far away from commune health centres seek help from traditional shamans ${ }^{12}$ before obtaining medical treatment. Similarly,

\footnotetext{
${ }^{8}$ McFadden (1977) suggests that the binomial logistic regression model is appropriate if the Pseudo R-square value falls in the range of 0.2 to 0.4 .

${ }^{9}$ See Appendix A, Table A4 for the prediction success of the poor and non-poor binomial logit regression model for the REM. We calculated the precision of the logit estimation without fitting the sample weights; in Stata, the command "lstat" (used to estimate the precision of logit model) is not available after estimation due adjustments made to account for sample weights. The results of the sampling unweighted logit model changed very little.

${ }^{10}$ We consider whether or not the types of toilets used by a household are associated with poverty. The type of toilet that a household uses is an indication of poverty (not able to afford a flush toilet is associated with poverty). The type of toilet a household uses is not the cause of poverty.

${ }^{11}$ Information about land quality is included only in the 2014 VHLSS, not in the 2012 and 2016 surveys. As suggested by Markussen. (2017), we use irrigated land in communes as a measure of land quality. We found the positive impact of irrigated land on REM's poverty reduction using commune-level data. For brevity, the result is unreported but available on request.

${ }^{12}$ A shaman is a religious specialist who is believed to have the ability to communicate with a non-human world (Pharo, 2011). In some ethnic minority communes in Vietnam, a shaman is considered to be an illness healer because s/he has the ability to search for the lost, wandering, or attacked soul and bring it back to the body in the human world (Pinson-Perez, Moua, \& Perez, 2005).
} 
Van de Walle and Gunewardena (2001), found that free healthcare for the REM is ineffective because they tend to visit shamans for treatment instead of the local healthcare centre. The authors also argued that the funds are allocated to development programmes that are not appropriate for ethnic minorities. In particular, they identified the national educational curriculum as ineffective in meeting the needs of the local people. However, this logit results indicate that scholarships have a positive impact on the REM's poverty rates. Credit programmes also have a strong impact on the REM's poverty rates. Holding other variables constant, the odds that a REM household is poor was reduced by $25 \%$.

c) Regional Characteristics. Poverty studies have identified the spatial effects on the likelihood that a household is poor (Epprecht et al., 2011; Mukherjee \& Benson, 2003; Ravallion, 1998). Similarly, we show that the probability of poverty depends on where REM reside. Our results show that during the study period very few poor ethnic minority people resided in the most developed region, southeast Vietnam (0.8\%) (see Table A4). In contrast, 94.4\% of the RPE lived in upland and coastal areas. The difficult geographic terrain and limited access to socio-economic centres partially explain why ethnic minority poverty is concentrated and persists in specific areas of Vietnam, i.e., the $\mathrm{CH}$ region or Northwest Vietnam. The logit results show that REM in the MNM region had a higher likelihood of living poverty than people in the RRD, MRD or southeast Vietnam. The Northern and Coastal Central and Central Highlands coefficients were insignificant, meaning that there was no difference in the probability that REM would be poor between the two regions and the MNM region.

\subsection{Impact of Household-Level Factors on Poverty Intensity}

a) Household Head Characteristics. Table 2 shows the fractional logit estimation results for REM at the household level. The result reveals that education and age were strong predictors of a poverty gap $(\mathrm{p}<0.01)$. Although it was positive in the REM fractional model, gender was not significant. These findings show that femaleheaded households do not have a wider poverty gap than male-headed households, holding other variables constant. For REM, marital status was not associated with a poverty gap.

Both non-farm and wage-paying employment significant decreased the poverty gap. However, the poverty gapreducing effect of wage-paying employment was larger than non-farm employment. In particular, the poverty gap was reduced by $6.6 \%$ for households whose heads have wage-paying employment compared with farming employment, holding other variables constant. Similarly, non-farm self-employment reduced the poverty gap by $5.8 \%$ compared with farming.

b) Household Characteristics. Larger households have a greater poverty gap. If REM households have one additional member, the poverty gap increases by $1.6 \%$. Likewise, the language barrier negatively affects the poverty gap $(\mathrm{p}<0.01)$. Regarding the AME, the result shows that the poverty gap increases by $1.4 \%$ for individuals who cannot speak Vietnamese (they can speak only their ethnic minority language) compared with native-Vietnamese speakers, holding other variables constant.

The ratio between the RPCE and the poverty line is decreased for REM who use clean water and flush toilets. Likewise, the poverty gap is reduced for REM who have a larger residential area and durable consumption expenditure. In the binary logit model, the impact of farmland area on the probability of poverty was not significant. However, a large farm holding (from 1 ha) reduced REM's poverty gap by 0.3 to $5.5 \%$ compared with a small farm holding (less than 0.5 ha). The study found a poverty intensity-decreasing effect for domestic and overseas remittances and health insurance premiums.

Of public assistance programmes, the credit programme had a strong impact on the intensity of poverty $(\mathrm{p}<0.01)$. Holding other variables constant, households that had access to the credit programme for the poor had a $4.8 \%$ narrower poverty gap than those who could not access such programmes. Having a pension also significantly reduced the poverty gap $(\mathrm{p}<0.1)$; a $1 \%$ increase in the pension was associated with a $0.8 \%$ reduction of poverty intensity. Scholarships and free health insurance both had no effect on REM's poverty gap. 
c) Regional Characteristics. REM's poverty gap depends heavily on differences in geographic and socio-economic conditions among the six regions in Vietnam. The poverty gap was smaller for households that were in RRD and MRD and Southeast, compared with those who lived in the MNM regions in which the poverty gap reducing-effect of residence in the MRD was the largest at 10.2\% ( $<<0.01)$. The Northern and Coastal Central coefficient was positive but insignificant; this means that living in the NCC region did not increase the poverty intensity when compared with living in the MNM region. In contrast, living in the $\mathrm{CH}$ region led to a wider poverty gap (1.8\%), compared with living the MNM region, holding other variables constant. These findings show that, during the study period, the $\mathrm{CH}$ was home to the poorest ethnic minority households. Similarly, the data in Figure 1 show that the RPE living in the $\mathrm{CH}$ region had the lowest expenditure.

\section{CONCLUSIONS AND POLICY RECOMMENDATIONS}

Using data from three recent national surveys, we have provided improved empirical evidence about the causes of persistent poverty and poverty intensity of ethnic minorities in rural Vietnam from 2012-2016. We applied a binary logistic regression model, a method commonly used in empirical studies, to estimate the probability that households is poor. Additionally, the study employed a fractional logit regression model that is more appropriate than the OLS and logit estimations to determine the poverty intensity, because it provides a fractional outcome variable bounded between 0 and 1 .

Results from both models show that low education levels, a large household size, poor sanitary conditions and a lack of healthcare or wage-paying employment strongly limit REM's capability to escape poverty. For example, the likelihood and intensity of poverty were reduced by $43 \%$ and $6.6 \%$ for household heads with salaried employment compared with those who worked in agricultural jobs, respectively. However, only $3 \%$ of the RPE had wage-paying employment. Education has a moderately positive effect on poverty: a one-year increase in education reduces the poverty gap by $0.4 \%$. Given that the mean of RPE's schooling years was five years (most only graduated from primary schools), if the RPE were to complete nine years of school (or graduate from secondary school), the poverty gap would be decreased by $1.6 \%$ (0.4\% multiplied by four years). Using the 2016 figures, this number is equivalent to VND 186 thousand increase in per capita annual expenditure (1.6\% of the 2016 poverty line). Similarly, domestic remittances and durable assets reduce poverty and its intensity.

Our results show that the majority of the REM reside in the most difficult geographic locations, such as in the upland or high mountains. Our results further reveal that living in remote and sparsely populated areas contributes to poor living standards and the severity of ethnic minority poverty in rural Vietnam. We supports the conceptual and theoretical model of the spatial effect of locations on poverty (Ravallion, 1998). Specifically, the Southeast, RRD and MRD regions have a lower likelihood and intensity of poverty compared with other areas. The $\mathrm{CH}$ region have the lowest living standard and the largest poverty gap. Therefore, to lift the poorest segment of the Vietnamese population out of poverty, the state budget allocation needs to target this region.

Our results show that the fractional logit models overcome limitations associated with the binary logit models that ignore some important determinants related to the depth of poverty. We found six variables that affect only the poverty intensity, not the probability of poverty: non-farm self-employment, language barrier, overseas remittances, farm sizes no less than 1 ha, pension, and Central Highlands. The binary logit model results show that scholarship help to reduce the probability of poverty. However, this factor appears to be insignificant in the fractional logit model. Using the linear regression models, the study proves that scholarship does not significantly improve the RPE's expenditure. ${ }^{13}$ This finding is consistent with the results of the fractional logit models.

\footnotetext{
${ }_{13}$ The OLS results are available on request.
} 
Previous authors argued that the anti-poverty policies have failed to tackle poverty in ethnic minority communes (Nguyen et al., 2017; Van de Walle \& Gunewardena, 2001). Our study supports this view. Our results show that free health insurance for the poor is ineffective in reducing REM's poverty; the free health insurance estimates were insignificant in both the binary and fractional logit models. However, we found that scholarship, pension and credit programmes had positive effects on poverty. Whereas the scholarship programme affects only the probability of poverty, the pension scheme affects only the poverty intensity. In contrast, the credit programme for the poor is highly effective because credit significantly decreases both the likelihood (25\%) and intensity (10\%) of poverty for participating households.

We provides policy planners with solutions to elevate REM's living standards and reduce their severe poverty. The study proposes solutions that build REM's human and physical capital, especially for the most marginalised people, such as people who speak only ethnic minority languages. Improving education is one solution that has a long-term impact on poverty reduction. It helps with building human resources, creates employment, and raises awareness about the importance of family planning. As lessons are taught in Vietnamese, removing language barriers would improve RPE's participation rates and, in turn, their futures. This would require the incorporation of Vietnamese classes and/or introducing bilingual school curriculums for those RPE who speak only ethnic minority languages. Moreover, government agencies/services such as healthcare and agricultural extension services should also provide information in ethnic minority languages. This would enable greater use of public services. In addition, rural diversification through increasing non-farm employment opportunities would reduce poverty levels and the poverty intensity. Another solution involves increasing access to development programmes, especially credit programmes.

Funding: This study received no specific financial support.

Competing Interests: The authors declare that they have no competing interests.

Acknowledgement: Authors thanked Dr Cuong Viet Nguyen for his comments and suggestions.

\section{REFERENCES}

Abrams, D., Nguyen, L. T., Murphy, J., Tran, N. K., \& Wiljer, D. (2016). Perceptions and experiences of perinatal mental disorders in rural, predominantly ethnic minority communities in Northern Vietnam. International Journal of Mental Health Systems, 1O(1), 1-10. Available at: https://doi.org/10.1186/s13033-016-0043-0.

Acharya, C. P., \& Leon-Gonzalez, R. (2012). The impact of remittance on poverty and inequality: A micro-simulation study for Nepal National Graduate Institute for Policy Studies Discussion Paper No. 11-26.

Baulch, B., \& Masset, E. (2003). Do monetary and nonmonetary indicators tell the same story about chronic poverty? A study of Vietnam in the 1990s. World Development, 31(3), 441-453. Available at: https://doi.org/10.1016/s0305-750x(02)002152.

Baulch, B., Nguyen, H. T. M., Phuong, P. T. T., \& Pham, H. T. (2010). Ethnic minority poverty in Vietnam. Working Paper No. 169. Chronic Poverty Research Centre.

Benjamin, D., Brandt, L., \& McCaig, B. (2017). Growth with equity: Income inequality in Vietnam, 2002-14. The Journal of Economic Inequality, 15(1), 25-46. Available at: https://doi.org/10.1007/s 10888-016-9341-7.

Bhaumik, S. K., Gang, I. N., \& Yun, M. S. (2006). A note on poverty in Kosovo. Journal of International Development: The Journal of the Development Studies Association, 18(8), 1177-1 187. Available at: https://doi.org/10.1002/jid.1283.

Bui, A. T., Nguyen, C. V., \& Pham, T. P. (2017). Poverty among ethnic minorities: The transition process, inequality and economic growth. Applied Economics, 49(31), 3114-3128. Available at: https://doi.org/10.1080/00036846.2016.1254341. 
Bui, T. P., \& Imai, K. S. (2019). Determinants of rural-urban inequality in Vietnam: Detailed decomposition analyses based on unconditional quantile regressions. The Journal of Development Studies, 55(12), 2610-2625. Available at: https://doi.org/10.1080/00220388.2018.1536265.

Coudouel, A., Jesko, H., \& Quentin, W. (2002). Poverty measurement and analysis. Munich, Germany: University Library of Munich, (MPRA Paper, No. 10490).

Dang, T. T. H. (2011). Poverty in Vietnam: The effects of shocks and sectoral growth patterns. Doctoral Thesis, University of Glasgow, UK.

Epprecht, M., Müller, D., \& Minot, N. (2011). How remote are Vietnam's ethnic minorities? An analysis of spatial patterns of poverty and inequality. The Annals of Regional Science, 46(2), 349-368. Available at: https://doi.org/10.1007/s00168009-0330-7.

Foster, J., Greer, J., \& Thorbecke, E. (1984). A class of decomposable poverty measures. Econometrica, 52(3), 761-766. Available at: https://doi.org/10.2307/1913475.

Gallup, J. L. (2004). The wage labor market and inequality in Vietnam. In D. Dollar, P. Glewwe, \& N. Agrawal. (Eds.), Economic Growth, Poverty, and Household Welfare in Vietnam (pp. 52-93). Washington, D.C: The World Bank.

Gibson, J., Le, T., \& Kim, B. (2017). Prices, Engel curves, and time-space deflation: Impacts on poverty and inequality in Vietnam. The World Bank Economic Revierw, 31(2), 504-530.

Glewwe, P., Agrawal, N., \& Dollar, D. (2004). Economic growth, poverty, and household welfare in Vietnam. Washington, D.C: The World Bank.

GSO. (2015). Result of the Vietnam household living standards survey 2012. Hanoi, Vietnam: Statistical Publishing House.

GSO. (2016). Result of the Vietnam household living standards survey 2014. Hanoi, Vietnam: Statistical Publishing House.

GSO. (2018). Statistical yearbook of Vietnam 2017. Hanoi, Vietnam: Statistical Publishing House.

Hinsdale, I., Marra, M., Kozel, V., Lanjouw, P., Brandt, L., Dat, V. H., \& Viet Cuong, N. (2013). 2012 Vietnam poverty assessment: Well begun, not yet done - Vietnam's remarkable progress on poverty reduction and the emerging challenges (No. 74910) (pp. 1-190). Washington D.C: The World Bank.

Imai, K. S., Gaiha, R., \& Kang, W. (2011). Poverty, inequality and ethnic minorities in Vietnam. International Review of Applied Economics, 25(3), 249-282. Available at: https://doi.org/10.1080/02692171.2010.483471.

Markussen, T. (2017). Land issues: Markets, property rights, and investment. In growth, structural transformation, and rural change in Viet Nam: A rising dragon on the move (pp. 117-138). Oxford, England: Oxford University Press.

McFadden, D. (1977). Quantitative methods for analyzing travel behavior of individuals: Some recent developments. Cowles Foundation Discussion Papers No. 474. Cowles Foundation for Research in Economics, Yale University.

Mukherjee, S., \& Benson, T. (2003). The determinants of poverty in Malawi, 1998. World Development, 31(2), 339-358. Available at: https://doi.org/10.1016/s0305-750x(02)00191-2.

Nguyen, H. T. M., Kompas, T., Breusch, T., \& Ward, M. B. (2017). Language, mixed communes, and infrastructure: Sources of inequality and ethnic minorities in Vietnam. World Development, 96, 145-162. Available at: https://doi.org/10.1016/j.worlddev.2017.03.004.

Osberg, L., \& Xu, K. (1999). Poverty intensity: How well do Canadian provinces compare? Canadian Public Policy/Analyse de Politiques, 25(2), 179-195. Available at: https://doi.org/10.2307/3551887.

Papke, L. E., \& Wooldridge, J. M. (1996). Econometric methods for fractional response variables with an application to 401 (k) plan participation rates. Journal of Applied Econometrics, 11(6), 619-632. Available at: https://doi.org/10.1002/(sici)1099-1255(199611)11:6\%3C6 19::aid-jae418\%3E3.0.co;2-1.

Papke, L. E., \& Wooldridge, J. M. (2008). Panel data methods for fractional response variables with an application to test pass rates. Journal of Econometrics, 145(1-2), 121-133. Available at: https://doi.org/10.1016/j.jeconom.2008.05.009.

Pham, H. L., Bui, T. Q., \& Dinh, M. H. (2003). Employment poverty linkages and policies for pro-poor growth in Vietnam. Issues in Employment and Poverty Discussion Paper No. 9; pp. 1-55). Geneva, Switzerland: Recovery and Reconstruction Department, International Labour Organization. 
Pharo, L. K. (2011). A methodology for a deconstruction and reconstruction of the concepts "Shaman" and "Shamanism". Numen, 58(1), 6-70. Available at: https://doi.org/10.1163/156852711x540087.

Pinson-Perez, H., Moua, N., \& Perez, M. A. (2005). Understanding satisfaction with shamanic practices among the Hmong in Rural California. International Electronic Journal of Health Education, 8, 18-23.

Ravallion, M. (1998). Poor areas. In A. Ullah \& D.E.A. Giles (Eds.), Handbook of applied economic statistics (pp. 63-91). New York, USA: Marcel Dekker, Inc.

Rodgers, J. R., \& Rodgers, J. L. (2000). Poverty intensity in Australia. Australian Economic Revierw, 33(3), 235-244. Available at: https://doi.org/10.1111/1467-8462.00151.

Tran, T. Q., Nguyen, S. H., Vu, H. V., \& Nguyen, V. Q. (2015). A note on poverty among ethnic minorities in the Northwest region of Vietnam. Post-Communist Economies, 27(2), 268-281. Available at: https://doi.org/10.1080/14631377.2015.1026716.

Tran, T. Q. (2016). Income sources and inequality among ethnic minorities in the Northwest region, Vietnam. Environment, Development and Sustainability, 18(4), 1239-1254. Available at: https://doi.org/10.1007/s10668-015-9700-8.

Van de Walle, D., \& Gunewardena, D. (2001). Sources of ethnic inequality in Viet Nam. Journal of Development Economics, 65(1), 177-207. Available at: https://doi.org/10.1016/s0304-3878(01)00133-x.

Vasavakul, T. (2003). Fighting words: Language policy and ethnic relations in Vietnam. London, England: MIT Press.

WB. (2009). Country social analysis: Ethnicity and development in Vietnam. Social Analysis No. 49976. Washington, D.C.: The World Bank.

WB. (2018). Climbing the ladder: Poverty reduction and shared prosperity in Vietnam (pp. 1-49). Washington, D.C: The World Bank.

\section{APPENDIX}

Table-A1. Definitions of binary and fractional logit model variables at the household level.

\begin{tabular}{|c|c|c|}
\hline Independent Variables & Description & Expected sign \\
\hline \multicolumn{3}{|c|}{ Household Head Characteristics } \\
\hline Age & Age of household heads (years) & $+/-$ \\
\hline Gender & Gender of household head, where female $=1$, male $=0$ & $+/-$ \\
\hline Education & $\begin{array}{l}\text { Household head's years of school attendance (number of } \\
\text { years) }\end{array}$ & - \\
\hline Marital Status & $\begin{array}{l}\text { Marital status of household head: } \text { single } / \text { never married }=1 \text {, } \\
\text { married }=2 \text { (base group), widowed }=3 \text {, divorced } / \text { separated }=4\end{array}$ & $+/-$ \\
\hline Occupation & $\begin{array}{l}\text { The employment sector in which household heads work as } \\
\text { their main job. agriculture }=1 \text { (base group), non-farm self- } \\
\text { employment }=2 \text {, wage-paying employment }=3\end{array}$ & - \\
\hline \multicolumn{3}{|c|}{ Household Characteristics } \\
\hline Poverty Status & Is the household poor or non-poor? Poor $=1$, non-poor $=0$. & + \\
\hline Rural Areas & The place where households live. Rural=1, urban $=0$. & + \\
\hline Ethnicity & $\begin{array}{l}\text { The religion of households, divided into the ethnic majority } \\
\text { (Kinh/Chinese) or minority (the remaining } 52 \text { ethnicities in } \\
\text { Vietnam), where minority }=1 \text {, majority }=0 \text {. }\end{array}$ & + \\
\hline Language Barriers & $\begin{array}{l}\text { Whether or not a household needs an interpreter during an } \\
\text { interview session. Yes }=1, \text { no }=0 \text {. }\end{array}$ & - \\
\hline Household Size & Number of family members in the household. & - \\
\hline Working Rate & $\begin{array}{l}\text { The percentage of working members in relation to total } \\
\text { family size (in \%). }\end{array}$ & - \\
\hline Living Area & Per capita land area $\left(\mathrm{m}^{2}\right)$ & - \\
\hline Durable Goods & $\begin{array}{l}\text { The logarithm of real per capita spending on durable goods } \\
\text { (in } 1,000 \text { VND). }\end{array}$ & - \\
\hline Water Sources & $\begin{array}{l}\text { The main water sources a household uses, where tap water } \\
=1 \text { (base group), clean and protected water }=2 \text {, other }=3 \text {. }\end{array}$ & + \\
\hline Toilets & The type of toilet a household has, where flush toilets $=1$, & - \\
\hline
\end{tabular}




\begin{tabular}{|c|c|c|}
\hline & $\begin{array}{l}\text { other toilets }=2 \text {, no toilet }=0 . \text { Other toilets include non-flush } \\
\text { toilets such as a suilabh, barrel/pot, and/or fishing bridge. }\end{array}$ & \\
\hline Domestic Remittances & $\begin{array}{l}\text { The logarithm of real per capita domestic remittances a } \\
\text { household receives (in } 1,000 \text { VND). }\end{array}$ & - \\
\hline Overseas Remittances & $\begin{array}{l}\text { The logarithm of real per capita overseas remittances a } \\
\text { household receives (in } 1,000 \text { VND). }\end{array}$ & - \\
\hline Farm Size & $\begin{array}{l}\text { The size of farmland (area) that a household manages or } \\
\text { uses, where Farm Size }=1 \text { if farmland }=0 \text { ha, } 2 \text { if } 0 \text { ha }< \\
\text { farmland area }<=0.5 \text { ha, } 3 \text { if } 0.5 \text { ha }<\text { farmland area }<=1 \text { ha, } \\
4 \text { if } 1 \text { ha }<\text { farmland area }<=1.5 \text { ha, } 5 \text { if farmland area }>1.5 \\
\text { ha. }\end{array}$ & - \\
\hline Health Insurance Premiums & $\begin{array}{l}\text { The percentage of family members who have purchased } \\
\text { health insurance }(\%) \text {. }\end{array}$ & - \\
\hline \multicolumn{3}{|l|}{ Development Programmes } \\
\hline Free Health Insurance Rate & $\begin{array}{l}\text { The percentage of family members who have free health } \\
\text { insurance }(\%) \text {. }\end{array}$ & - \\
\hline Scholarship & $\begin{array}{l}\text { The logarithm of real per capita scholarship a household } \\
\text { receives (in } 1,000 \text { VND). }\end{array}$ & - \\
\hline Pension & $\begin{array}{l}\text { The logarithm of real per capita pension a household } \\
\text { receives (in } 1,000 \mathrm{VND} \text { ). }\end{array}$ & - \\
\hline Borrowing & $\begin{array}{l}\text { Whether or not a household borrows money from the } \\
\text { preferred credit programmes implemented by the Social } \\
\text { Policy Bank and other organisations such as the Farmer's } \\
\text { Association and the Women's Association, where yes }=1 \text {, } \\
\text { no=0. }\end{array}$ & - \\
\hline \multicolumn{3}{|l|}{ Regional Characteristics } \\
\hline Region 1 & $\begin{array}{l}\text { Households live in Midlands and Northern Mountains (base } \\
\text { group for REM models), where yes }=1, \mathrm{no}=0 \text {. }\end{array}$ & + \\
\hline Region2 & $\begin{array}{l}\text { Households live in Red River Delta (base group for TH, } \\
\text { TRH models), where yes }=1, \text { no }=0 \text {. }\end{array}$ & - \\
\hline Region3 & $\begin{array}{l}\text { Households live in Northern and Coastal Central, where } \\
\text { yes }=1, n o=0 \text {. }\end{array}$ & - \\
\hline Region4 & Households live in Central Highlands, where yes=1, no=0. & - \\
\hline Region5 & Households live in Southeast, where yes $=1$, no $=0$. & $+/-$ \\
\hline Region6 & $\begin{array}{l}\text { Households live in Mekong River Delta, where yes }=1 \text {, } \\
\text { no=0. }\end{array}$ & $+/-$ \\
\hline \multicolumn{3}{|l|}{ Survey Year } \\
\hline Interview year & $\begin{array}{l}\text { The year in which the survey was conducted. Year } 2012=1 \\
\text { (base year), year } 2014=2 \text {, year } 2016=3 \text {. }\end{array}$ & - \\
\hline
\end{tabular}


Asian Development Policy Review, 2021, 9(3): 161-179

Table A2. Structure of annual real per capita income of rural ethnic minorities, 2012-2016 (VND 1,000).

\begin{tabular}{|c|c|c|c|c|c|c|c|c|c|c|c|c|c|c|c|c|c|c|}
\hline \multirow[b]{3}{*}{ Income Sources } & \multicolumn{6}{|c|}{2012} & \multicolumn{6}{|c|}{2014} & \multicolumn{6}{|c|}{2016} \\
\hline & \multicolumn{2}{|c|}{ All } & \multicolumn{2}{|c|}{ Poor } & \multicolumn{2}{|c|}{ Non-Poor } & \multicolumn{2}{|c|}{ All } & \multicolumn{2}{|c|}{ Poor } & \multicolumn{2}{|c|}{ Non-Poor } & \multicolumn{2}{|c|}{ All } & \multicolumn{2}{|c|}{ Poor } & \multicolumn{2}{|c|}{ Non-Poor } \\
\hline & Mean & $\%$ & Mean & $\%$ & Mean & $\%$ & Mean & $\%$ & Mean & $\%$ & Mean & $\%$ & Mean & $\%$ & Mean & $\%$ & Mean & $\%$ \\
\hline Agriculture & 4419.5 & 52.4 & 3288.0 & 59.1 & 6186.9 & 47.8 & 4321.6 & 47.5 & 3186.3 & 55.8 & 6058.2 & 42.4 & 4229.1 & 42.0 & 3020.5 & 51.4 & 5306.2 & 38.4 \\
\hline Non-Agriculture & 559.5 & 6.6 & 151.3 & 2.7 & 1197.1 & 9.3 & 597.4 & 6.6 & 100.4 & 1.8 & 1357.5 & 9.5 & 783.3 & 7.8 & 117.6 & 2.0 & 1376.5 & 10.0 \\
\hline Wages & 2555.2 & 30.3 & 1481.9 & 26.6 & 4231.8 & 32.7 & 3274.2 & 36.0 & 1790.4 & 31.4 & 5543.9 & 38.8 & 3842.6 & 38.2 & 2028.7 & 34.5 & 5459.1 & 39.6 \\
\hline Remittances & 448.3 & 5.3 & 237.1 & 4.3 & 778.1 & 6.0 & 384.4 & 4.2 & 178.0 & 3.1 & 700.0 & 4.9 & 588.0 & 5.8 & 224.5 & 3.8 & 911.9 & 6.6 \\
\hline From Domestic & 322.0 & 3.8 & 228.1 & 4.1 & 468.7 & 3.6 & 339.8 & 3.7 & 168.4 & 2.9 & 602.0 & 4.2 & 512.6 & 5.1 & 208.2 & 3.5 & 783.9 & 5.7 \\
\hline From Overseas & 126.3 & 1.5 & 9.0 & 0.2 & 309.5 & 2.4 & 44.6 & 0.5 & 9.6 & 0.2 & 98.1 & 0.7 & 75.4 & 0.7 & 16.3 & 0.3 & 128.0 & 0.9 \\
\hline Aids & 154.0 & 1.8 & 145.2 & 2.6 & 167.6 & 1.3 & 194.8 & 2.1 & 205.2 & 3.6 & 178.7 & 1.3 & 241.1 & 2.4 & 246.1 & 4.2 & 236.6 & 1.7 \\
\hline For Education & 108.5 & 1.3 & 117.5 & 2.1 & 94.5 & 0.7 & 147.7 & 1.6 & 178.6 & 3.1 & 100.3 & 0.7 & 174.3 & 1.7 & 224.5 & 3.8 & 129.5 & 0.9 \\
\hline For Healthcare & 45.4 & 0.5 & 27.7 & 0.5 & 73.1 & 0.6 & 47.1 & 0.5 & 26.6 & 0.5 & 78.4 & 0.5 & 66.8 & 0.7 & 21.6 & 0.4 & 107.1 & 0.8 \\
\hline Other & 302.9 & 3.6 & 257.6 & 4.6 & 373.6 & 2.9 & 322.5 & 3.5 & 247.7 & 4.3 & 436.8 & 3.1 & 385.0 & 3.8 & 243.4 & 4.1 & 511.1 & 3.7 \\
\hline Total & 8439.3 & 100 & 5561.1 & 100 & 12935.0 & 100 & 9094.8 & 100 & 5708.0 & 100 & 14275.2 & 100 & 10069.0 & 100 & 5880.8 & 100 & 13801.3 & 100 \\
\hline
\end{tabular}

Note: Means are calculated at the constant prices of January 2010. Estimates are accounted for the sampling weight 
Table-A3. Characteristics of rural ethnic minorities at the household level.

\begin{tabular}{|c|c|c|c|c|c|c|c|}
\hline \multirow[t]{2}{*}{ Continuous/Discrete Variables } & \multicolumn{2}{|c|}{ All } & \multicolumn{2}{|c|}{$\begin{array}{c}\text { Rural Poor } \\
\text { Ethnic Minorities }\end{array}$} & \multicolumn{2}{|c|}{$\begin{array}{l}\text { Rural Non-poor } \\
\text { Ethnic Minorities }\end{array}$} & \multirow{2}{*}{$\begin{array}{c}\text { t-value/ } \\
\text { Pearson } \\
\text { Chi }^{2}\end{array}$} \\
\hline & Mean & SD & Mean & SD & Mean & SD & \\
\hline Age & 44.53 & 12.59 & 43.11 & 12.92 & 46.32 & 11.93 & **** \\
\hline Education & 5.01 & 3.81 & 4.11 & 3.59 & 6.14 & 3.78 & ***** \\
\hline Household Size & 5.04 & 1.77 & 5.44 & 1.80 & 4.54 & 1.60 & **** \\
\hline Proportion of Working Member & 61.76 & 21.87 & 57.36 & 19.69 & 67.33 & 23.19 & ***** \\
\hline Living Area/Residential & 14.77 & 10.06 & 11.72 & 6.44 & 18.62 & 12.25 & ***** \\
\hline Durable Goods (logarit) & 5.91 & 1.52 & 5.27 & 1.55 & 6.72 & 1.01 & **** \\
\hline Durable Goods (VND 1,000) & 779.40 & 1682.72 & 362.36 & 324.37 & 1305.70 & 2403.56 & ***** \\
\hline Domestic Remittances (logarit) & 3.55 & 2.48 & 3.22 & 2.30 & 3.95 & 2.64 & ***** \\
\hline Domestic Remittances (VND 1,000) & 398.59 & 1770.04 & 201.10 & 805.27 & 647.82 & 2481.73 & **** \\
\hline Overseas Remittances (logarit) & 0.07 & 0.74 & 0.02 & 0.43 & 0.12 & 1.01 & $* * *$ \\
\hline Overseas Remittances (VND 1,000) & 81.72 & 1668.76 & 11.45 & 300.74 & 170.41 & 2484.46 & *** \\
\hline Health Insurance Premiums & 18.37 & 34.51 & 9.40 & 25.75 & 29.68 & 40.35 & ***** \\
\hline Free Health Insurance & 90.15 & 24.81 & 93.94 & 20.12 & 85.36 & 28.99 & **** \\
\hline Scholarship (logarit) & 0.23 & 0.96 & 0.21 & 0.95 & 0.26 & 0.98 & \\
\hline Scholarship (VND 1,000) & 9.71 & 100.04 & 8.97 & 78.87 & 10.63 & 121.63 & \\
\hline Pension (logarit) & 0.14 & 1.09 & 0.05 & 0.64 & 0.26 & 1.47 & ***** \\
\hline Pension (VND 1,000) & 103.86 & 1092.33 & 21.21 & 322.95 & 208.17 & 1596.42 & **** \\
\hline \multicolumn{8}{|l|}{ Dummy/Categorical Variables } \\
\hline Female & 0.12 & 0.32 & 0.11 & 0.31 & 0.13 & 0.33 & **** \\
\hline Never Married & 0.01 & 0.10 & 0.01 & 0.10 & 0.01 & 0.11 & **** \\
\hline Married & 0.90 & 0.29 & 0.91 & 0.28 & 0.89 & 0.31 & ***** \\
\hline Widowed & 0.07 & 0.26 & 0.07 & 0.25 & 0.08 & 0.28 & **** \\
\hline Divorced/Separated & 0.01 & 0.10 & 0.01 & 0.10 & 0.01 & 0.10 & **** \\
\hline Agriculture & 0.87 & 0.34 & 0.93 & 0.26 & 0.79 & 0.41 & $* * *$ \\
\hline Non-farm Self-Employment & 0.06 & 0.24 & 0.04 & 0.19 & 0.10 & 0.29 & **** \\
\hline Wage-Paying Employment & 0.07 & 0.25 & 0.03 & 0.17 & 0.11 & 0.32 & ***** \\
\hline Language Barriers & 0.28 & 0.45 & 0.39 & 0.49 & 0.15 & 0.36 & **** \\
\hline Tap Water & 0.05 & 0.21 & 0.03 & 0.16 & 0.07 & 0.26 & ***** \\
\hline Clean Water & 0.39 & 0.49 & 0.29 & 0.45 & 0.52 & 0.50 & **** \\
\hline Other Water & 0.56 & 0.50 & 0.68 & 0.47 & 0.41 & 0.49 & **** \\
\hline Toilet_Flush & 0.16 & 0.37 & 0.06 & 0.24 & 0.29 & 0.46 & $* * *$ \\
\hline Toilet_Not Flush & 0.62 & 0.49 & 0.62 & 0.49 & 0.62 & 0.49 & **** \\
\hline Toilet_No & 0.22 & 0.41 & 0.32 & 0.47 & 0.09 & 0.29 & ***** \\
\hline No-Farmland & 0.05 & 0.21 & 0.03 & 0.16 & 0.07 & 0.26 & **** \\
\hline $\mathrm{o}$ ha $<=$ Farm Size $<0.5$ ha & 0.27 & 0.44 & 0.26 & 0.44 & 0.27 & 0.45 & **** \\
\hline 0.5 ha $<=$ Farm Size $<1$ ha & 0.19 & 0.39 & 0.20 & 0.40 & 0.17 & 0.37 & **** \\
\hline 1 ha $<=$ Farm Size $<1.5$ ha & 0.16 & 0.37 & 0.17 & 0.37 & 0.15 & 0.36 & ***** \\
\hline Farm Size $>=1.5$ ha & 0.34 & 0.47 & 0.34 & 0.47 & 0.34 & 0.47 & **** \\
\hline Borrowing/Credit & 0.32 & 0.47 & 0.31 & 0.46 & 0.33 & 0.47 & **** \\
\hline Red River Delta & 0.02 & 0.16 & 0.01 & 0.12 & 0.04 & 0.19 & ***** \\
\hline Midlands and Northern Mountains & 0.52 & 0.50 & 0.54 & 0.50 & 0.49 & 0.50 & $* * *$ \\
\hline Northern and Coastal Central & 0.20 & 0.40 & 0.22 & 0.42 & 0.16 & 0.37 & **** \\
\hline Central Highlands & 0.15 & 0.36 & 0.18 & 0.38 & 0.12 & 0.32 & **** \\
\hline Southeast & 0.02 & 0.16 & 0.01 & 0.09 & 0.05 & 0.21 & **** \\
\hline Mekong River Delta & 0.08 & 0.28 & 0.03 & 0.18 & 0.14 & 0.35 & **** \\
\hline
\end{tabular}

Note: Means and Standard Deviations (SD) accounted for the sampling weights. Differences between means/proportions of the poor and the non-poor are statistically significant at $1 \%$, except for overseas remittances $(\mathrm{p}$-value $<0.05)$ and scholarship ( $\mathrm{p}$-value $>0.1)$. 
Table-A4. Binary logit estimation without sampling weight for REM at the household level.

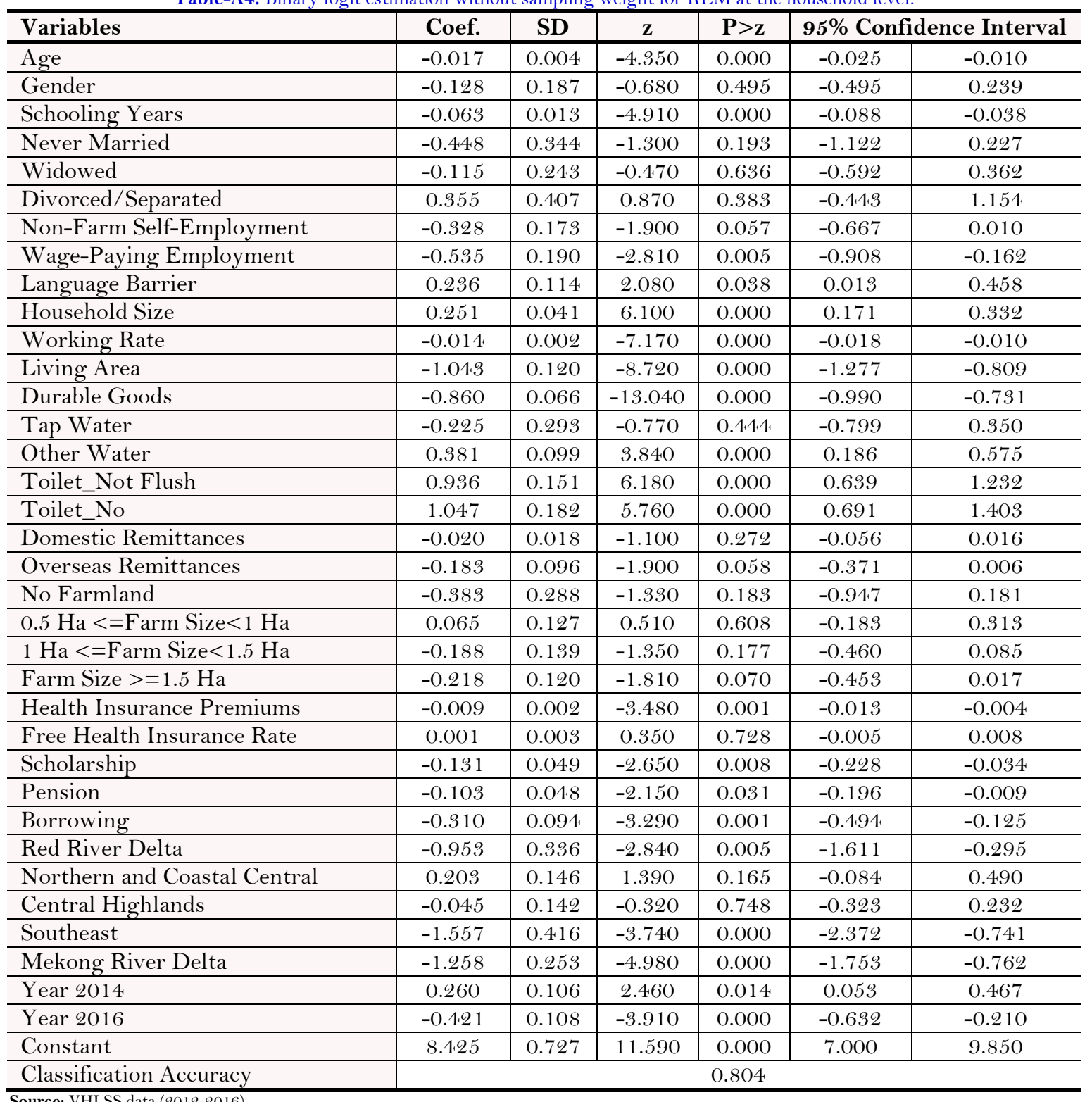

